\title{
Larger Canna Leafroller, Calpodes ethlius (Stoll) (Insecta: Lepidoptera: Hesperiidae) ${ }^{1}$
}

Heather J. McAuslane and Kim King ${ }^{2}$

\section{Introduction}

Flowering canna plants (several species of Canna) make beautiful additions to the landscape in Florida home gardens and on public or commercial property. Cannas (see University of Florida Fact Sheet "Cannas for the Florida Landscape") are easy to grow, have few disease problems, and produce lush tropical-looking foliage and showy colorful flowers. However, cannas can be decimated by leaf-chewing insects, such as grasshoppers and leaf-rolling caterpillars. Two caterpillars, in particular, are very destructive to canna in Florida, the larger canna leafroller, Calpodes ethlius (Stoll), whose adult form is variously called the Brazilian skipper, the canna butterfly, or the arrowroot butterfly (Moore 1928), and the lesser canna leafroller, Geshna cannalis (Quaintance) .

\section{Distribution}

Calpodes ethlius is native to Mexico, Central America, and the northern part of the South American continent, being found as far south as the northern border of Argentina (Scudder 1889). It is found on the Galapagos Islands in the Pacific Ocean (Onore and Mielke 1988) and throughout the West Indies in the Caribbean Sea. In the United States, it is well-established in Florida, Texas, and southern Arizona (Scudder 1889). It is an occasional visitor to other Gulf coastal states and can be found in coastal Georgia and South Carolina. To date, C. ethlius has been collected in at least 24 states (see Butterflies of North America), although many of those records are considered to be "strays" rather than indications of establishment.

\section{Description and Life History}

The adults of $C$. ethlius are brownish skipper butterflies of medium size. The female's forewing ranges from 22 to $27 \mathrm{~mm}$ in length while that of the male is somewhat smaller at 23 to $24 \mathrm{~mm}$ (Scudder 1889). The forewings are rich dark brown except for five vitreous (= transparent) spots and have a fringe of dirty golden yellow hairs on the posterior margin. The hind wings are a little darker than the forewings and have three vitreous spots arranged in an almost

1. This document is EENY-132, one of a series of Featured Creatures from the Entomology and Nematology Department, Florida Cooperative Extension Service, Institute of Food and Agricultural Sciences, University of Florida. Published: May 2000. Reviewed: May 2004. This document is also available on Featured Creatures Website at http://creatures.ifas.ufl.edu. Please visit the EDIS Website at http://edis.ifas.ufl.edu. Additional information on these organisms, including many color photographs, is available at the Entomology and Nematology Department website at http://entnemdept.ifas.ufl.edu/.

2. Heather J. McAuslane, Entomology and Nematology Department, University of Florida, Gainesville, FL and Kim King, University of Western Ontario, London, Ontario, Canada.

The Institute of Food and Agricultural Sciences (IFAS) is an Equal Employment Opportunity - Affirmative Action Employer authorized to provide research, educational information and other services only to individuals and institutions that function without regard to race, creed, color, religion, age, disability, sex, sexual orientation, marital status, national origin, political opinions or affiliations. For information on obtaining other extension publications, contact your county Cooperative Extension Service office. Florida Cooperative Extension Service / Institute of Food and Agricultural Sciences / University of Florida / Larry R. Arrington, Interim Dean 
straight line. The dorsal surface of the thorax is olive-colored while the ventral surface is yellowish gray. The abdomen is dark brown dorsally and pale yellow whitish ventrally. Adult skippers are strong, fast fliers and can usually only be collected while they nectar at flowering plants. In southern Florida, adults are usually first noticed in May with a second generation of adults appearing in early June. It is not known how many generations per year occur in Florida but adults have been collected in all months of the year (Kimball 1965) and all larval stages have been collected in January. It is thought that $C$. ethlius can only overwinter in the very southernmost region of Florida and must recolonize more northern regions each year (Moore 1928).

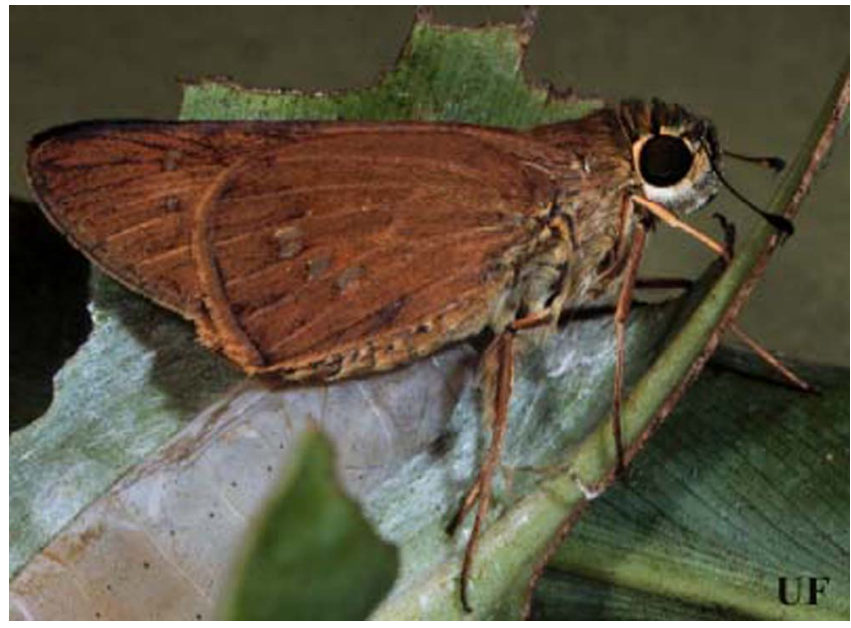

Figure 1. Adult of the larger canna leafroller, Calpodes ethlius (Stoll), in normal resting position. Credits: Paul M. Choate, University of Florida

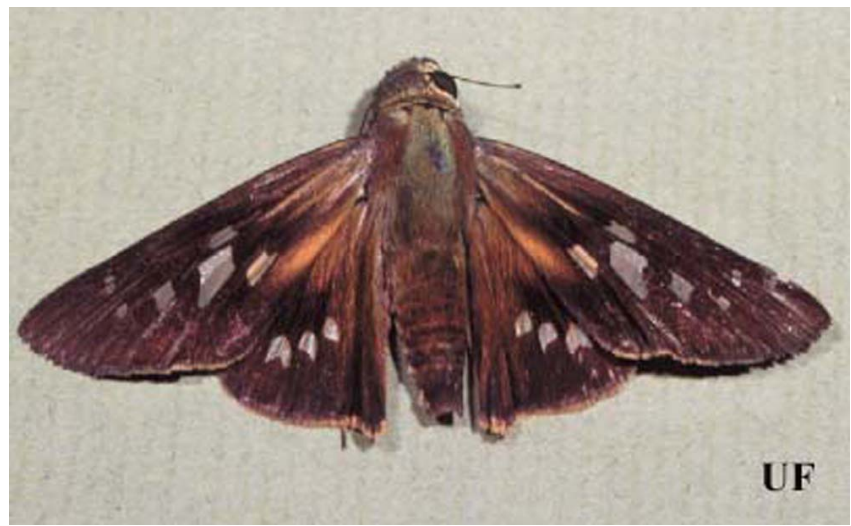

Figure 2. Adult of the larger canna leafroller, Calpodes ethlius (Stoll), with wings spread to show characteristic markings. Credits: Paul M. Choate, University of Florida

Female $C$. ethlius lay eggs singly or in widely spaced groups of five to seven eggs on the upper and lower surfaces of canna leaves (Scudder 1889). The egg measures about $1.25 \mathrm{~mm}$ in diameter and 0.68 $\mathrm{mm}$ in height. It is a pale green color when first deposited and, within a day, becomes a distinct pink color (Moore 1928).

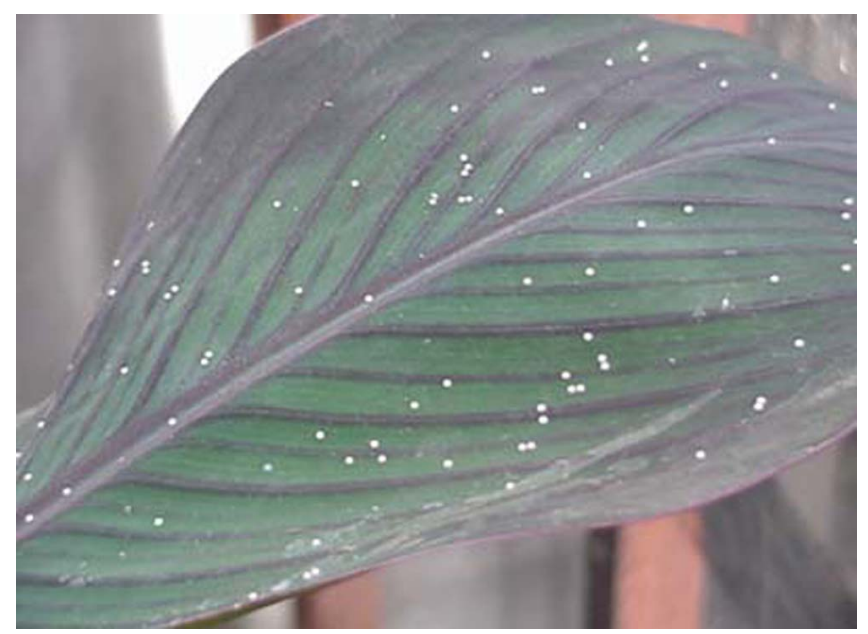

Figure 3. Eggs of the larger canna leafroller, Calpodes ethlius (Stoll), on canna leaf. Credits: Kim King, University of Western Ontario, London, Ontario, Canada

The first-instar larva ecloses after four to five days under Florida summer conditions and is approximately $4 \mathrm{~mm}$ in length and yellowish in color (Scudder 1889; Cockerell 1892). Its head is very large, black, glossy and bilobed. The thoracic shield, legs and anal tip are also black. The larva consumes most of its egg shell (King 1880) and then moves to the margin of the leaf where it eats two narrow strips from the margin of the leaf towards the midrib producing a leaf flap (Moore 1928). The larva fastens silken strands between the outer edge of the leaf flap and the main portion of the leaf. As the silk shrinks or condenses as it dries, the leaf flap is drawn over the caterpillar, making a flattened tubular shelter with exits at either end. The larva keeps the majority of its body within the leaf roll, only extending its head to feed. The leaf roll may serve as both protection from predators and direct sun. The first instar molts to the next stage after three days.

The remaining four larval instars range in length from 5 to $50 \mathrm{~mm}$. The second through fourth instars have a dark brown, almost black, head and a dark green body that is semi-transparent, allowing the organs and tracheal system to be seen through the integument. The larvae appear dark green because of the leaf material within their guts. There is a white 
stripe on each side of the dorsum of the larva running the length of the body. The fifth instar has an orange head with a dark triangle on the frontal region. The larvae consume most of the leaf around their leaf roll and then move to another area of the leaf, when necessary. They roll a bigger leaf roll as they outgrow the previous one. Several large larvae may defoliate an entire canna plant in this manner. The larvae have an interesting behavior of flicking away frass so that their leaf roll remains free of pellets and instead, frass accumulates on the ground. Fecal firing (see reference below) is facilitated by the anatomy of the larva's anal comb and the buildup of hemostatic pressure within its terminal abdominal segment (Caveney et al. 1998). It is hypothesized that frass removal may reduce discovery by parasites and predators which often use the odor and sight of frass as clues to the potential presence of hosts or prey.

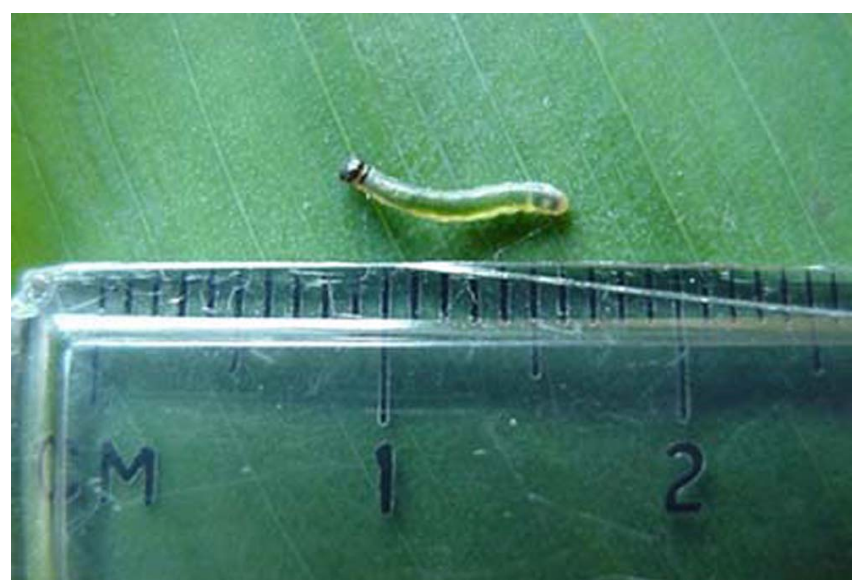

Figure 4. Second instar larva of the larger canna leafroller, Calpodes ethlius (Stoll). Credits: Kim King, University of Western Ontario, London, Ontario, Canada

The larva feeds voraciously during the final, fifth instar stage. As it prepares for pupation, the larva ceases feeding and empties its gut of leaf material. It shortens in length and becomes bright bluish green. This prepupal stage lasts from one to eight days in Florida, depending on the ambient temperature (Moore 1928). The larva pupates within its leaf roll after first having spun a thin silken mat covering the "floor" of its shelter. The chrysalis is bright green in color (Cockerell 1892) and is approximately $36 \mathrm{~mm}$ in length (Scudder 1889). It has a pronounced black

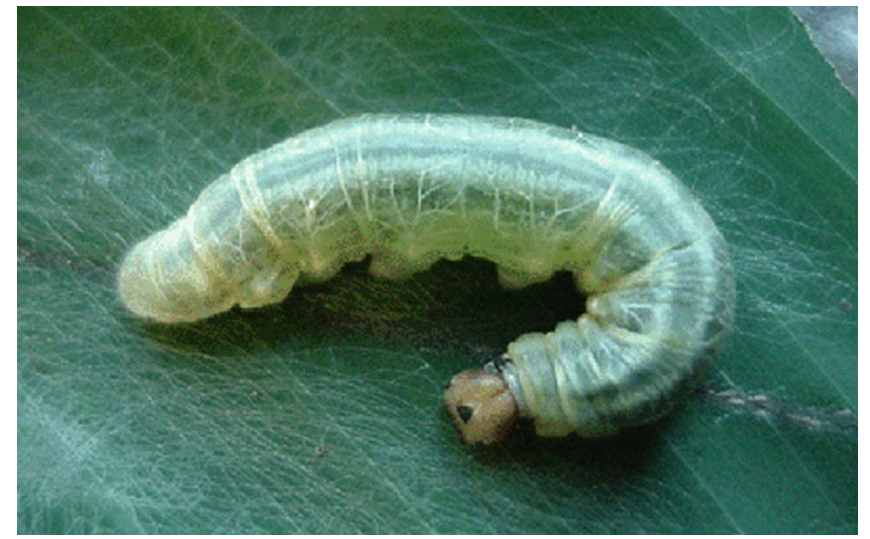

Figure 5. Fifth instar larva of the larger canna leafroller, Calpodes ethlius (Stoll), with characteristic dark triangle on frontal region of the head. Credits: Kim King, University of Western Ontario, London, Ontario, Canada

spine at the anterior end and the long proboscis of the adult is enclosed in a case that extends beyond the cremaster at the tip of the abdomen. The pupal stage lasts seven to eight days in the summer in Florida.

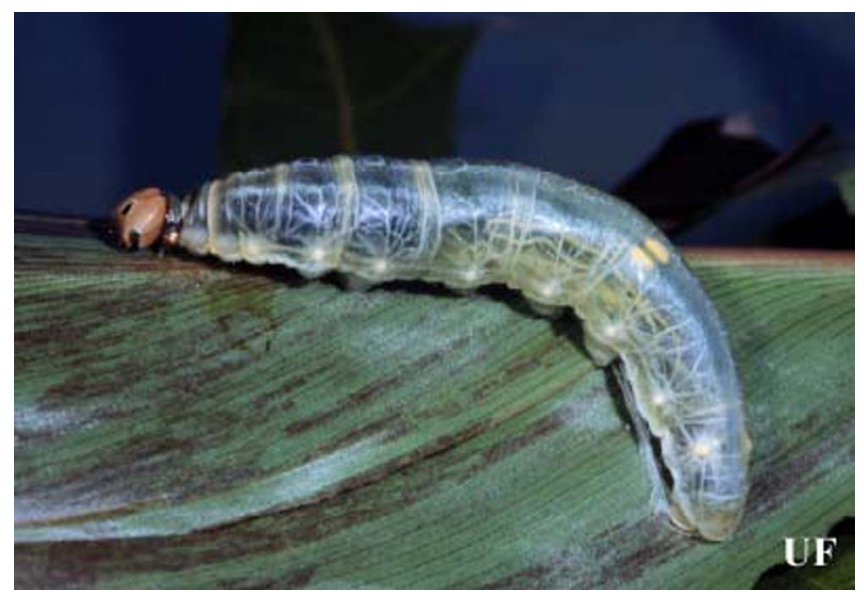

Figure 6. Fifth instar larva of the larger canna leafroller, Calpodes ethlius (Stoll), before gut emptying. Credits: Paul M. Choate, University of Florida

\section{Host Plants and Damage}

The host plants of $C$. ethlius include members of the Cannaceae family, which contains the single genus, Canna. Calpodes ethlius has also been collected from West Indian arrowroot, Maranta arundinacea $\mathrm{L}$., of the closely-related family Marantaceae. Leaf rolling reduces the aesthetic appeal of ornamental canna and voracious leaf feeding by larger larvae may be so severe that plants do not flower (Young 1982). In food crops, such as arrowroot, severely defoliated plants may produce little of the harvestable rhizome. 


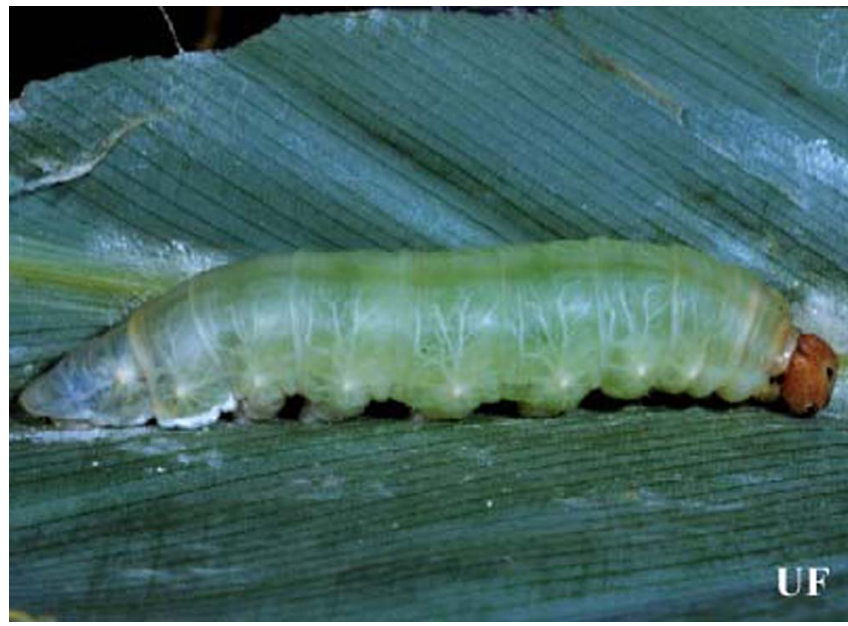

Figure 7. Fifth instar larva of the larger canna leafroller, Calpodes ethlius (Stoll), after gut emptying in preparation for pupation. Credits: Paul M. Choate, University of Florida

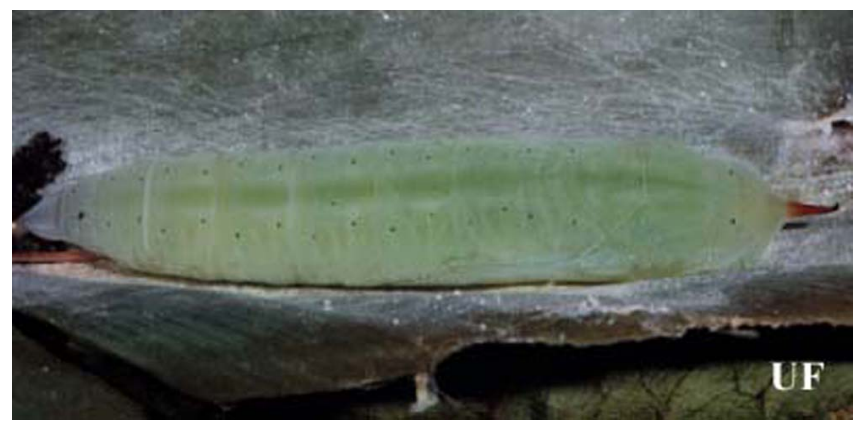

Figure 8. Pupa of the larger canna leafroller, Calpodes ethlius (Stoll), on silken mat in leaf roll. Credits: Paul M. Choate, University of Florida

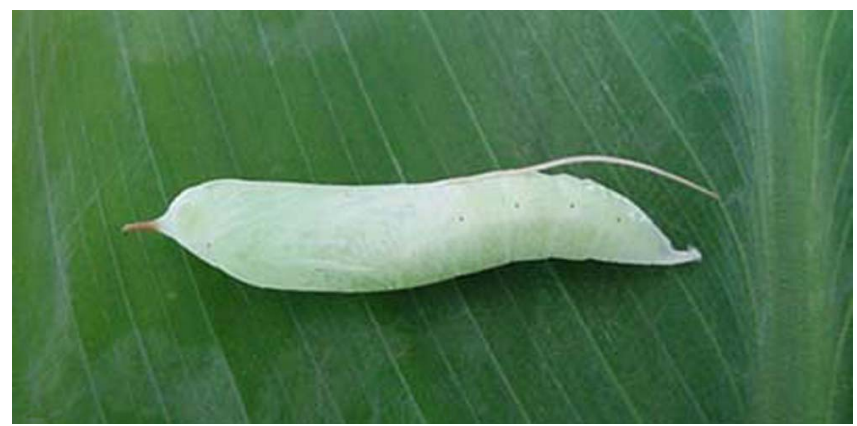

Figure 9. Pupa of the larger canna leafroller, Calpodes ethlius (Stoll), showing anterior spine and case enclosing proboscis extending beyond cremaster. Credits: Kim King, University of Western Ontario, London, Ontario, Canada

\section{Management}

In 1981, 39 canna varieties were evaluated for host plant resistance to egg-laying (= oviposition) and larval feeding by C. ethlius (Reinert et al. 1983). In general, the red-leaved varieties (especially 'Wyoming', 'Black Velvet', and 'Ambassador')

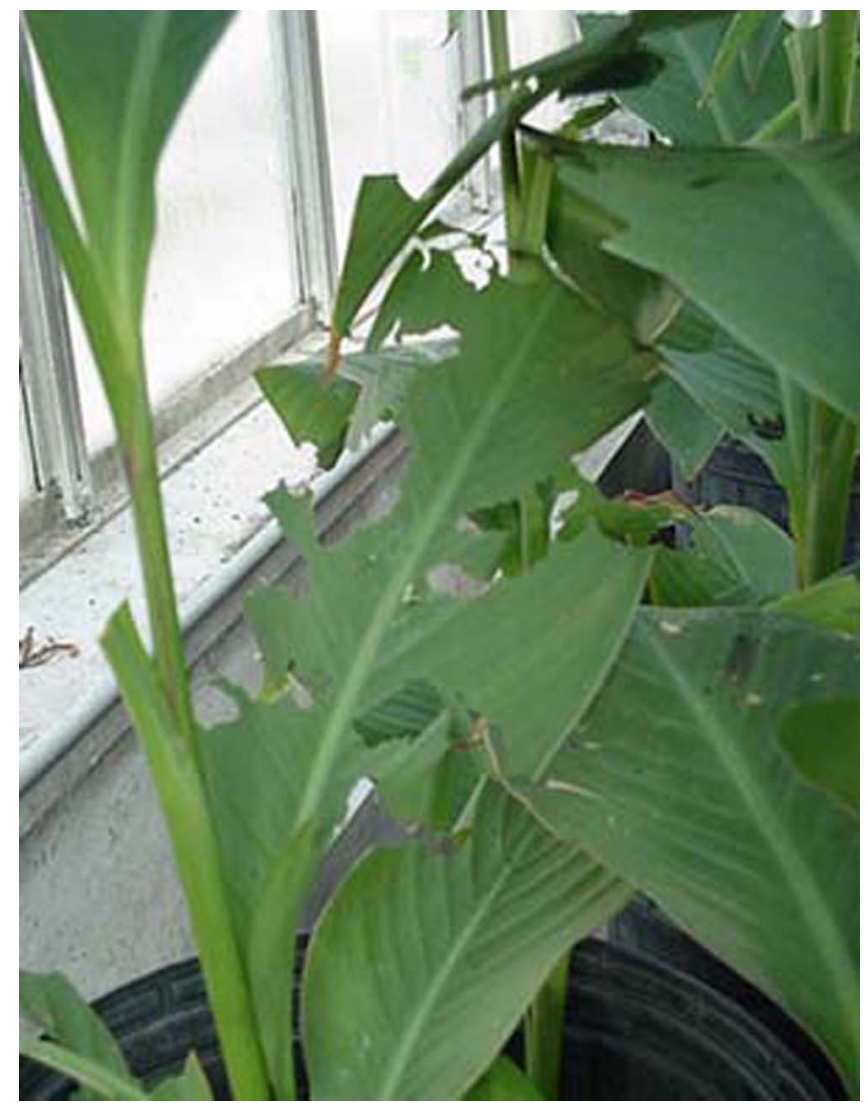

Figure 10. Canna leaf damage caused by larvae of the larger canna leafroller, Calpodes ethlius (Stoll). Credits: Kim King, University of Western Ontario, London, Ontario, Canada

received many more eggs than the green-leaved varieties. Varieties with scarlet, red, or orange flowers, regardless of leaf color, tended to experience more oviposition and larval feeding damage than varieties with other flower colors. Although varieties have been identified that are particularly susceptible to the Brazilian skipper, none has been identified as resistant.

Little attention has been paid to biological control of $C$. ethlius in ornamental canna. However, this skipper attacks arrowroot, $M$. arundinacea, which is an important food crop in the Caribbean region. A very small (0.8-1.2 $\mathrm{mm}$ in length) parasitic wasp, Ooencyrtus calpodicus Noyes (Hymenoptera: Encyrtidae), was found in Trinidad attacking eggs of C. ethlius and was introduced into other Caribbean islands for control of this species (Noyes 1985). Ooencyrtus calpodicus has not been recorded from the United States, however. Three hymenopteran parasites have been recorded from C. ethlius in Florida; Brachymeria incerta (Cresson) 
(Chalicididae) parasitizing pupae and Xenufens ruskini Girault (Trichogrammatidae) (Krombein et al. 1979) and Trichogramma minutum Riley

(Trichogrammatidae) parasitizing eggs (Moore 1928). Parasitic tachinid flies, including Eucelatoria australis Townsend, Eusisyropa blanda (Osten Sacken), and Lixophaga diatraeae (Townsend), have emerged from pupae in Florida (Arnaud 1978). I have noted infection by pathogens which cause the larvae to turn black, liquify and disintegrate. There is probably considerable natural mortality of $C$. ethlius in Florida due to parasitism, predation, and diseases but obviously not enough to keep populations from heavily defoliating cannas in certain years.

Chemical control is difficult because larvae are protected from direct chemical exposure within their leaf rolls. If deemed necessary, chemical control should be attempted when larvae are small and are still actively feeding on the leaves. Bacillus thuringiensis $(\mathrm{Bt})$ products are probably the best choice for chemical control. Follow the application instructions on the label of the specific Bt product. Stickers will probably need to be added to the spray because the thick waxy coating on canna leaves repels water. Other chemical insecticides are described in:

Insect Management on Landscape Plants (http://edis.ifas.ufl.edu/IG013)

Commercial Foliage and Woody Ornamental Arthropod Pest Management (http://edis.ifas.ufl.edu/IG012)

\section{Selected References}

Arnaud, P. H. Jr. 1978. A host-parasite catalog of North American Tachinidae (Diptera). Misc. Publ. No. 1319. USDA, Washington, D.C.

Caveney, S., H. McLean, and D. Surry. (1998). Faecal firing in a skipper caterpillar is pressure-driven. J. Exp. Biol. 201: 121-133. http://www.biologists.com/JEB/201/01/jeb1194.html (20 May 2000).

Cockerell, T. D. A. 1892. Notes on the life-history of Calpodes ethlius. Entomol. News 3: 78- 80.
Kimball, C. P. 1965. The Lepidoptera of Florida: An annotated checklist. Division of Plant Industry, State of Florida Department of Agriculture, Gainesville, Florida.

King, H. S. 1880. Internal organization of Hesperia ethlius Cram. as observed in the living animal. Pysche 3: 322-342.

Krombein, K. V., P. D. Hurd, Jr., D. R. Smith, and B. D. Burks. 1979. Catalog of Hymenoptera in America north of Mexico. Vol. 1. Symphyta and Apocrita (Parasitica). Smithsonian Institution Press, Washington, D.C.

Moore, M. B. 1928. A study of the life history and habits under Florida conditions of the canna butterfly (Brazilian skipper), Calpodes ethlius (Cramer), an insect pest of the canna. M.S. thesis, University of Florida, Gainesville. 95 p.

Onore, G. and O. Mielke. 1988. Calpodes ethlius (Cramer) (Lepidoptera, Hesperiidae) em Gal pagos. Rev. Bras. Zool. 5: 619-620.

Opler, P. A., H. Pavulaan, and R. E. Stanford (coordinators). (1995). Butterflies of North America. Jamestown, ND: Northern Prairie Wildlife Research Center. http://www.npwrc.usgs.gov/resource/distr/lepid/ bflyusa/bflyusa.htm (20 May 2000).

Reinert, J. A., T. K. Broschat, and H. M. Donselman. 1983. Resistance of Canna spp. to the skipper butterfly, Calpodes ethlius (Lepidoptera: Hesperiidae). Environ. Entomol. 12: 1829- 1832.

Scudder, S. H. 1889. Calpodes ethlius - the Brazilian skipper, pp. 1750-1757. In The Butterflies of the Eastern United States and Canada with Special Reference to New England. Vol. II Lycaenidae, Papilionidae, Hesperidae. S. H. Scudder Publ., Cambridge.

Young, A. M. 1982. Notes on the interaction of the skipper butterfly Calpodes ethlius (Lepidoptera: Hesperiidae) with its larval host plant Canna edulis (Cannaceae) in Mazatlan, state of Sinaloa, Mexico. New York Entomol. Soc. 90: 99-114. 